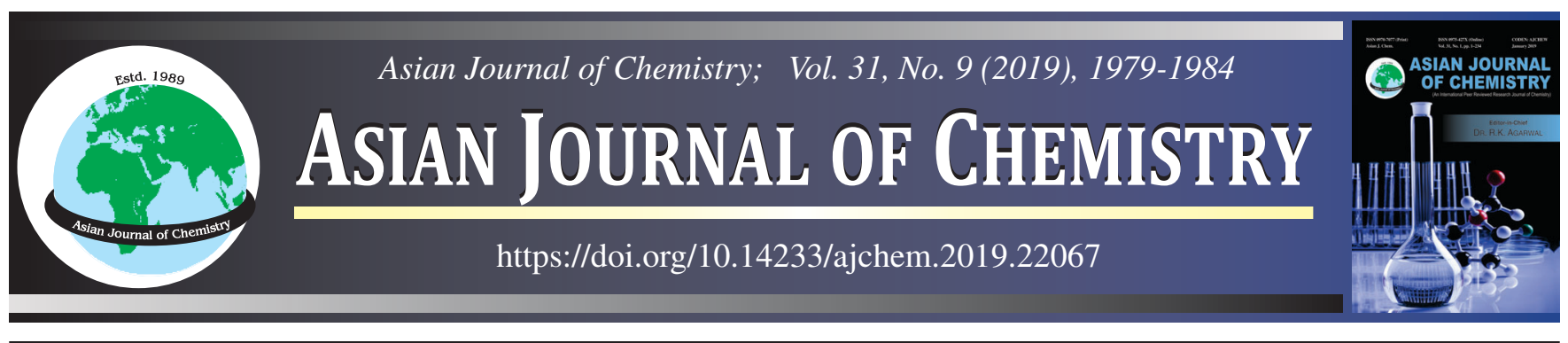

\title{
Synthesis, Characterization and Antimicrobial Activities of Copper(II) Complexes of Schiff Base Ligand 2-[(3'-N-salicylidinephenyl)benzimidazole]
}

\section{B. RoOPASHREE ${ }^{1, *}, \bullet$ and V. GAYATHRI ${ }^{2, \bullet}$}

${ }^{1}$ Department of Chemistry, J.S.S. Academy of Technical Education, (Affiliated to Visvesvaraya Technological University), Bengaluru-560060, India

${ }^{2}$ Department of Post Graduate Studies in Chemistry, Central College Campus, Bangalore University, Bengaluru-560001, India

*Corresponding author: Fax: +91 80 28612706; E-mail: roopajss@ gmail.com

Received: 12 March 2019;

Accepted: 17 April 2019;

Published online: 31 July 2019;

AJC-19485

$\mathrm{CuX}_{2} \cdot 6 \mathrm{H}_{2} \mathrm{O}\left(\mathrm{X}=\mathrm{Cl}^{-}, \mathrm{Br}^{-}\right.$or $\left.\mathrm{ClO}_{4}^{-}\right)$reacted with a Schiff base ligand 2-[(3'-N-salicylidinephenyl)benzimidazole $]$in 1:2 mole ratio in methanol to yield brown colored complexes of types $\left[\mathrm{CuCl}_{2} \mathrm{~L}\right]_{2},\left[\mathrm{CuBr}_{1.5} \mathrm{~L}_{1.5}\right]_{2} \mathrm{Br}$ and $\left[\mathrm{Cu}\left(\mathrm{OClO}_{3}\right) \mathrm{L}_{2}\right]_{2}\left(\mathrm{ClO}_{4}\right)_{2} \cdot 4 \mathrm{H}_{2} \mathrm{O}$. The complexes were characterized by analytical and spectroscopic studies such as elemental analysis, conductivity and magnetic moment measurements, thermogravimetric analysis, IR, far-IR, electronic, ESR and mass spectral studies. IR spectral studies suggested the coordination of ligand to the central metal atom via tertiary nitrogen of benzimidazole and nitrogen of azomethine group. Based on these studies, binuclear structure was proposed for all the copper complexes. The ligand and its copper(II) complexes were screened for antibacterial and antifungal activities.

Keywords: Schiff base, Benzimidazole, Copper(II) complexes, Biological activity.

\section{INTRODUCTION}

Benzimidazoles are the promising class of biologically significant $N$-heterocycles and are abundant in naturally occurring drugs such as omeprazole, astemizole and emedastine difumarate [1]. Transition metal complexes with biologically important $\mathrm{N}$-donor ligands have gained the significance for their application in the pharmaceutical industry, interesting magnetic properties, finding application as corrosion inhibitors for metals and alloys. Transition metal complexes with 2-substituted benzimidazole ligands exhibit cytotoxic, antiviral and antiamoebic properties [2-6]. Schiff bases have the ability to reversibly bind oxygen, catalytic activity in the hydrogenation of olefins and exhibit photochromism and thermochromism [7] and hence have been used as ligands in coordination chemistry. Metal complexes of biologically important ligands are many a times more effective than uncoordinated $N$-heterocycles. Metal complexes of Schiff-base ligands have significant applications in bioinorganic chemistry because many of these complexes serve as biological models in understanding the structure of biologically important molecules and processes [8-11].
Schiff base of salicylaldehyde and its derivatives are studied to a greater extent due to their unusual magnetic properties, novel structural features and importance to biological systems [12-16].

Copper is a vital trace element necessary for all the living organisms. It plays significant role as a fundamental constituent of many enzymes. Copper complexes display variations in coordination geometry, excellent colours, unusual magnetic properties, technical application dependent molecular structures and spectroscopic properties and their biochemical significance $[17,18]$. Diverse geomentries are displayed by copper(II) ion with the same ligand and is known as plasticity effect $[17,19,20]$ as a consequence of Jahn-Teller distortion of $\mathrm{Cu}$ (II) ion. Coordination complexes of copper(II) ion with benzimidazole ligands are studied as models for copper proteins [21-25]. Copper salts and copper complexes also exhibit antibacterial, antifungal properties and have applications in ion exchange resins [26,27]. In view of this, we report herein the synthesis, structural characterization and antimicrobial studies of copper(II) complexes of Schiff base ligand formed by the condensation of $m$-aminophenyl benzimidazole and salicylaldehyde.

This is an open access journal, and articles are distributed under the terms of the Attribution 4.0 International (CC BY 4.0) License. This license lets others distribute, remix, tweak, and build upon your work, even commercially, as long as they credit the author for the original creation. You must give appropriate credit, provide a link to the license, and indicate if changes were made. 


\section{EXPERIMENTAL}

All the reagents were of analytical grade. The solvents used were purified according to standard procedure [28]. Hydrated copper halides were obtained from BDH. Hydrated perchlorate was prepared by dissolving copper(II) carbonate in 1:2 aqueous perchloric acid, evaporating the resulting solution to almost dryness under reduced pressure. Standard drugs were obtained from Ranbaxy, India.

Microanalyses were obtained from ElementarVario EL III and TGA was recorded on Perkin Elmer, Diamond TG/DTA with a heating rate of $15{ }^{\circ} \mathrm{C} \mathrm{min}{ }^{-1}$ in nitrogen atmosphere at Sophisticated Test and Instrumentation Centre (STIC), Cochin, India. IR (nujol mull) spectra were recorded on Shimadzu FTIR 8400 s spectrometer. Far-IR spectra were recorded on Thermo Nicolet model; 6700 spectrometer and magnetic susceptibility measurements were recorded by VSM method at Central Instrumentation Facility, Pondicherry University, Pondicherry, India. Electronic spectra were recorded in DMF on Shimadzu UV 3101PC spectrophotometer. Molar conductivity measurements were made on a Systronic conductivity meter 304-cell Type CD-10. ESI mass spectra were recorded on a Micromass Quattro II triple quadrupole mass spectrometer at SAIF, CDRI, Lucknow. ESR spectra were recorded on ESR-SVarian,USA make, E-112 ESR Spectrometer model at SAIF, IIT, Bombay.

Biological activity: Antimicrobial activities were carried out by agar diffusion method. The ligand 2-[(3'-N-salicylidinephenyl)benzimidazole], its $\mathrm{Cu}(\mathrm{II})$ complexes and standard drug dissolved in DMSO $(2.5 \mu \mathrm{g} / 0.1 \mathrm{~mL})$ were used for testing antimicrobial activity. Peptone $(0.6 \%)$, beef extract $(0.15 \%)$, sodium chloride, dextrose and agar (2\%) were dissolved in $1000 \mathrm{~mL}$ of distilled water at $7.4 \mathrm{pH}$ to form nutrient agar media. The medium was autocalved at $121^{\circ} \mathrm{C}$ for $15 \mathrm{~min}$ at $15 \mathrm{lb}$ pressure/sq. inch. The mixture was cooled to $45^{\circ} \mathrm{C}$. Fresh culture ( $6 \mathrm{~g}$ of peptone, $1.5 \mathrm{~g}$ of beef extract, $1 \mathrm{~g}$ of dextrose, $15 \mathrm{~g}$ of agar and $5 \mathrm{~g}$ of sodium chloride in $1000 \mathrm{~mL}$ of distilled water) was added, mixed well and the medium was allowed to solidify. In each petridish, five wells were made using a sterile borer. $0.1 \mathrm{~mL}$ of test solution $(2.5 \mu \mathrm{g} / 0.1 \mathrm{~mL})$, standard solution and DMSO control were poured into separate wells in each plate. The petridish was covered and incubated at $37^{\circ} \mathrm{C}$ for $24 \mathrm{~h}$. Zone inhibitions were observed and average three readings were recorded.

Pathogenic fungi were isolated by inoculating infected sample into corn meal agar. The inoculated plates were incubated at $28{ }^{\circ} \mathrm{C}$ for 2 days. The colonies thus formed were selected for further screening. The Sabouraud's agar medium was prepared for the organisms. The medium was sterilized, fresh culture of fungi and ampicillin were added to prevent bacterial growth at a concentration $25 \mu \mathrm{g} / 30 \mathrm{~mL}$ of the culture medium and the plates were prepared. In each petridish, five wells were made using a sterile borer. $0.1 \mathrm{~mL}$ of test solution of concentration $2.5 \mathrm{mg} / 0.1 \mathrm{~mL}$, standard solution and DMSO control were poured into separate wells in each plate. The petridishes were covered and incubated at $28{ }^{\circ} \mathrm{C}$ for $48 \mathrm{~h}$. Zone inhibitions were observed and average three readings were recorded.

Synthesis of 2-[(3'-N-salicylidinephenyl)benzimidazole]: A new Schiff base ligand, 2-[( $3^{\prime}$-N-salicylidinephenyl)benzimidazole] was prepared by the condensation of methanolic solution of $m$-aminophenyl benzimidazole [29] with salicylaldehyde at refluxing temperature for $6 \mathrm{~h}$. The reaction mixture was concentrated to get yellow coloured compound (Fig. 1). The solid was filtered, dried and recrystallized in methanol. The X-ray crystallographic studies of the ligand is reported elsewhere [30]. m.p. $=235^{\circ} \mathrm{C}$, Yield $=76 \%$.

Synthesis of $\left[\mathrm{Cu}\left(\mathrm{OClO}_{3}\right) \mathrm{L}_{2}\right]_{2}\left(\mathrm{ClO}_{4}\right)_{2} \cdot 4 \mathrm{H}_{2} \mathrm{O},\left[\mathrm{CuCl}_{2} \mathrm{~L}\right]_{2}$ and $\left[\mathrm{CuBr}_{1.5} \mathbf{L}_{1.5}\right]_{2} \mathrm{Br}$ complexes: To $1 \mathrm{mmol}$ of hydrated $\mathrm{CuX}_{2} \cdot 6 \mathrm{H}_{2} \mathrm{O}\left(\mathrm{X}=\mathrm{Cl}^{-}, \mathrm{Br}^{-}\right.$or $\left.\mathrm{ClO}_{4}^{-}\right)$in $12 \mathrm{~mL}$ of methanol and triethyl orthoformate mixture (3:1), $10 \mathrm{~mL}$ of methanolic solution of Schiff base ligand ( $2 \mathrm{mmol}$ ) was added. The reaction mixture was heated under reflux for $6 \mathrm{~h}$ during which a brown solids got separated. The solids were filtered, washed with methanol and dried in a vacuum (Yield 60-70 \%).

\section{RESULTS AND DISCUSSION}

Copper halides/perchlorate react with 2-[(3'-N-salicylidinephenyl)benzimidazole] in 1:2 mole ratio in methanol/teof mixture to yield brown coloured complexes of the types $\left[\mathrm{CuCl}_{2} \mathrm{~L}\right]_{2}$ $\left[\mathrm{CuBr}_{1.5} \mathrm{~L}_{1.5}\right]_{2} \mathrm{Br}$ and $\left[\mathrm{Cu}\left(\mathrm{OClO}_{3}\right) \mathrm{L}_{2}\right]_{2}\left(\mathrm{ClO}_{4}\right)_{2} \cdot 4 \mathrm{H}_{2} \mathrm{O}$.

The complex, $\left[\mathrm{CuCl}_{2} \mathrm{~L}\right]_{2}$ was insoluble in common organic solvents but soluble in DMF and DMSO in which it behaved as non-electrolyte. The $\left[\mathrm{CuBr}_{1.5} \mathrm{~L}_{1.5}\right]_{2} \mathrm{Br}$ exhibited 1:1 electrolytic behavior in DMSO and $\left[\mathrm{Cu}\left(\mathrm{OClO}_{3}\right) \mathrm{L}_{2}\right]_{2}\left(\mathrm{ClO}_{4}\right)_{2} \cdot 4 \mathrm{H}_{2} \mathrm{O}$ exhibited 1:2 electrolytic behaviour [31].

The TGA studies for the complex was restricted to 300 ${ }^{\circ} \mathrm{C}$ to determine the nature of water molecules present in the complex. The complex, $\left[\mathrm{Cu}\left(\mathrm{OClO}_{3}\right) \mathrm{L}_{2}\right]_{2}\left(\mathrm{ClO}_{4}\right)_{2} \cdot 4 \mathrm{H}_{2} \mathrm{O}$ lost water molecules within $100^{\circ} \mathrm{C}$ indicating the presence of lattice water in the complex. The results are in accordance with the composition of the complex as determined by elemental analyses. The physical properties and analytical data of the compounds are listed in Table-1.

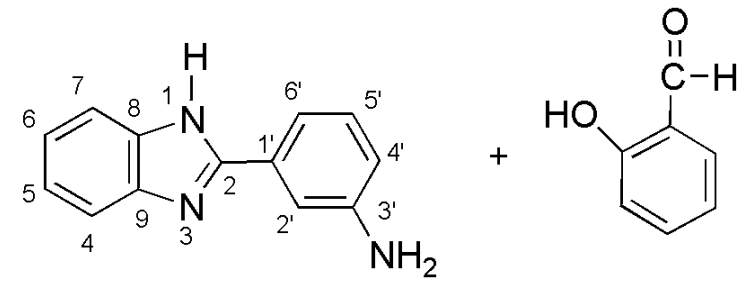

m-aminophenyl benzimidazole
Salicylaldehyde

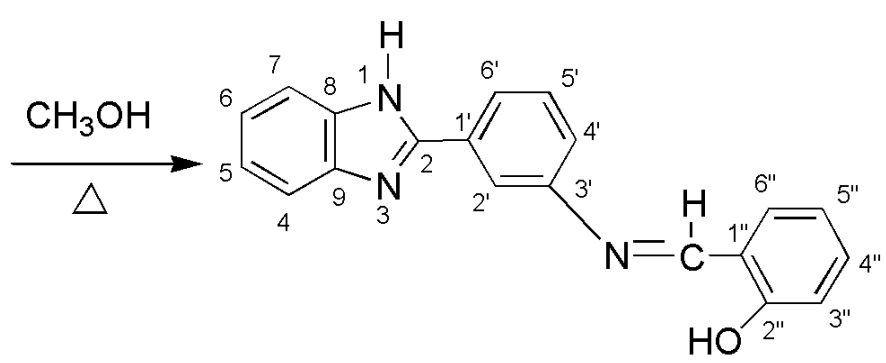

2-[(3'-N-salicylidinephenyl)benzimidazole]

Fig. 1. Preparation of 2-[(3'-N-salicylidinephenyl)benzimidazole] 
TABLE-1

PHYSICAL PROPERTIES AND ANALYTICAL DATA

\begin{tabular}{|c|c|c|c|c|c|c|c|}
\hline \multirow{2}{*}{ Complex } & \multirow{2}{*}{ Colour } & \multirow{2}{*}{$\begin{array}{c}\text { m.p../d.p. } \\
\left({ }^{\circ} \mathrm{C}\right)\end{array}$} & \multirow{2}{*}{$\Lambda^{\mathrm{a}}$} & \multirow{2}{*}{$\mu_{\mathrm{eff}}{ }^{*}$} & \multicolumn{3}{|c|}{ Elemental analysis (\%): Found (calcd.) } \\
\hline & & & & & $\mathrm{C}$ & $\mathrm{H}$ & $\mathrm{N}$ \\
\hline Ligand & Yellow & 235 & - & - & $76.92(76.66)$ & $4.96(4.83)$ & $13.38(13.42)$ \\
\hline$\left[\mathrm{CuCl}_{2} \mathrm{~L}\right]_{2}$ & Brown & $>280$ & 28 & 1.1 & $53.60(53.60)$ & $3.00(3.30)$ & $9.70(9.40)$ \\
\hline$\left[\mathrm{CuBr}_{1.5} \mathrm{~L}_{1.5}\right]_{2} \mathrm{Br}$ & Brown & 235 & $38^{\mathrm{b}}$ & 0.92 & $51.30(51.66)$ & $3.60(3.25)$ & $9.00(9.03)$ \\
\hline$\left[\mathrm{Cu}\left(\mathrm{OClO}_{3}\right) \mathrm{L}_{2}\right]_{2}\left(\mathrm{ClO}_{4}\right)_{2} \cdot 4 \mathrm{H}_{2} \mathrm{O}$ & Green & $>280$ & $88^{\mathrm{b}}$ & 0.94 & $51.70(51.93)$ & $4.00(3.70)$ & $9.30(9.08)$ \\
\hline
\end{tabular}

$\Lambda$ in $\Omega^{-1} \mathrm{~cm}^{2} \mathrm{~mol}^{-1}$; a in DMF, b in DMSO, *Bohr magneton

IR spectral studies: The IR spectra of the ligand and its copper(II) complexes were recorded as nujol mull (Table-2). The spectra of all the complexes were similar to that of uncoordinated $N$-heterocycle except for minor shifts in the position of the peaks. The IR spectrum of the ligand showed the absence of peaks due to $\mathrm{v}_{\mathrm{NH}_{2}}$ or $\mathrm{v}_{\mathrm{C}-\mathrm{O}}$ of the precursor $m$-aminophenyl benzimidazole and salicyladehyde which suggested the complete formation of azomethine linkage [32-35]. A peak at $1312 \mathrm{~cm}^{-1}$ and shift in $v_{\mathrm{C}-\mathrm{N}}$ and $v_{\mathrm{O}-\mathrm{H}}$ compared to the vibrations in usual Schiff bases suggested the presence of intramolecular $\mathrm{H}$-bonding between $\mathrm{OH}$ group and the azomethine nitrogen atom [36]. Schiff base ligand can coordinate to central metal ion through nitrogen of benzimidazole moiety and/or azomethine nitrogen or oxygen of hydroxyl group after deprotonation. The free ligand displayed $v_{\mathrm{C}-\mathrm{N}}$ at $1618 \mathrm{~cm}^{-1}$ due to benzimidazole moiety and azomethine group. This peak was shifted upon complexation, indicating the participation of the tertiary nitrogen of benzimidazole moiety and/or azomethine group in the metal coordination sphere. Hence, the Schiff base ligand can behave as both monodentate as well as bridging bidentate ligand. The $v_{\mathrm{C}-\mathrm{N}}$ and $\delta_{\mathrm{N}-\mathrm{H}}, \mathrm{v}_{\mathrm{N}-\mathrm{H}}$ and $v_{\mathrm{O}-\mathrm{H}}$ of the uncoordinated $\mathrm{N}$-heterocycle appeared at 1312, 3157 and $3471 \mathrm{~cm}^{-1}$, respectively [37]. The characteristic band of $\mathrm{C}-\mathrm{OH}$ group of salicyladehyde lowered by the H-bonding, which was observed at $1115 \mathrm{~cm}^{-1}$ in the spectrum of ligand. The $v_{\mathrm{O}-\mathrm{H}}$ of the complexes was found in the range 3534-3300 $\mathrm{cm}^{-1}$ which indicated that oxygen of O-H was not involved in the coordination. The IR spectral data of the complex containing water molecules displayed a broad peak in the range $3534-3300 \mathrm{~cm}^{-1}$ assigned for $\mathrm{v}_{\mathrm{O}-\mathrm{H}}$ of water molecule and salicylidine moiety. The perchlorato complex of copper exhibited peaks at 1184, 1156, 1100, 1045 and 621 $\mathrm{cm}^{-1}$ indicative of the presence of both coordinated as well as ionic perchlorate groups [38], which was also supported from the conductivity data.

The far-IR spectrum of chloro complex of copper displayed peak due to only terminal $v_{\mathrm{Cu}-\mathrm{Cl}}$ at $282 \mathrm{~cm}^{-1}$ while its bromo analogue exhibited peaks corresponding to both bridging as well as terminal bromides at 188 and $259 \mathrm{~cm}^{-1}$, respectively.

NMR spectral studies of 2-[(3'-N-salicylidinephenyl)benzimidazole]: The structural and spectroscopic assignments was made through the combined use of 1-D and 2-D NMR experiments such as COSY, HSQC and HMBC experiments carried out for the ligand.

The ${ }^{1} \mathrm{H}$ NMR spectrum of the ligand exhibited a singlet at $12.80 \mathrm{ppm}$ due to imine and $\mathrm{OH}$ protons. A singlet at 8.20 ppm was assigned to 2 ' proton. Spectrum exhibited a multiplet at $7.23 \mathrm{ppm}$ and a triplet at $7.01 \mathrm{ppm}$ which were assigned to 4,7 and $4^{\prime \prime}, 3^{\prime \prime}$ protons of benzimidazole unit and salicylidine unit, respectively. Phenylene ring proton 4 ' exhibited a doublet at $7.54 \mathrm{ppm}$. A triplet at $7.44 \mathrm{ppm}$ was due to a proton at $5^{\prime \prime}$. Protons 5, 6 and $5^{\prime}$ exhibited a multiplet at $7.62 \mathrm{ppm}$. Doublets at 8.12 and $7.72 \mathrm{ppm}$ were assigned to protons of $6^{\prime}$ of phenyl and 6 " of salicylidine moiety, respectively. Azomethine proton exhibited a singlet at $9.08 \mathrm{ppm}$.

The ${ }^{13} \mathrm{C}$ NMR spectrum of ligand exhibited peaks in the range $115 \mathrm{ppm}$ to $165 \mathrm{ppm}$. Quaternary carbons $2,(8 \& 9),\left(1^{\prime}\right.$ $\left.\& 1^{\prime \prime}\right), 3^{\prime} \& 2^{\prime \prime}$ exhibited peaks at 150.66, 131.36, 160.30, 148.34 and $119.30 \mathrm{ppm}$, respectively. The signals at 122.24 and $130.12 \mathrm{ppm}$ were assigned to benzimidazole ring carbons $(4,7)$ and $(5,6)$, respectively. Phenyl ring carbons $2^{\prime}, 4^{\prime},\left(5^{\prime} \& 6^{\prime}\right)$ exhibited signals at 119.40, 122.51 and $124.77 \mathrm{ppm}$, respectively. The resonance signals at $119.23,116.64,133.50$ and 132.54 ppm were due to salicylidine ring carbon atoms $3^{\prime \prime} 4^{\prime \prime}, 5^{\prime \prime}$ and 6 ", respectively. A resonance signal at $163.97 \mathrm{ppm}$ was assigned to azomethine carbon atom.

2D-Homonuclear and heteronuclear techniques have assisted the complete analysis of the resonances of ligand. The COSY spectrum of ligand showed the cross peaks between the protons $\left(4^{\prime} \& 5^{\prime}\right),\left(5^{\prime} \& 6^{\prime}\right),\left(3^{\prime \prime} \& 4^{\prime \prime}\right),\left(4^{\prime \prime} \& 5^{\prime \prime}\right),\left(5^{\prime \prime} \& 6^{\prime \prime}\right)$. In order to make unambiguous assignments of the resonances, PFG-HSQC and PFG-HMBC $[39,40]$ experiments had been carried-out. The ${ }^{13} \mathrm{C}$ NMR spectrum of ligand showed fifteen resonances for the carbons. Cross peaks were observed for the protons 4,5 , $6,7,2^{\prime}, 4^{\prime}, 5^{\prime}, 6^{\prime}, 3^{\prime \prime}, 4^{\prime \prime}, 5^{\prime \prime}, 6^{\prime \prime}$ and C-H proton of imine group with the corresponding carbons. The PFG-HMBC experiment of the ligand displayed carbon-proton correlation of long range or multiple bonds. For multiple bonds connectivity or longrange information, this provided support for the assignment of resonances of the quaternary carbons $2,8,9,1^{\prime}, 3^{\prime}, 1^{\prime \prime}$ and $2^{\prime \prime}$. The resonances due to the quaternary carbons $1^{\prime \prime}$ and $1^{\prime}$

TABLE-2

IR AND FAR-IR SPECTRAL DATA $\left(\mathrm{cm}^{-1}\right)$

\begin{tabular}{|c|c|c|c|c|c|c|c|}
\hline Complex & $v_{\mathrm{O}-\mathrm{H}}$ & $\begin{array}{c}v_{\mathrm{N}-\mathrm{H}} \text { of } \\
\text { benzimidazole }\end{array}$ & $v_{\mathrm{C}=\mathrm{N}}$ & $\begin{array}{c}v_{\mathrm{C}-\mathrm{N}} \& \\
\delta_{\mathrm{N}-\mathrm{H}}\end{array}$ & $\begin{array}{c}V_{\mathrm{M}-\mathrm{X}_{(\mathrm{b})}} \\
\mathrm{x}=\mathrm{Cl} / \mathrm{Br}\end{array}$ & $\begin{array}{c}\mathrm{V}_{\mathrm{M}-\mathrm{X}_{(\mathrm{t})}} \\
\mathrm{x}=\mathrm{Cl} / \mathrm{Br}\end{array}$ & $\mathrm{v}_{\mathrm{ClO}_{4}}$ \\
\hline Ligand & 3471 & 3157 & 1618 & 1312 & - & - & - \\
\hline$\left[\mathrm{CuCl}_{2} \mathrm{~L}\right]_{2}$ & 3400 & 3138 & 1615 & 1282 & - & 282 & - \\
\hline$\left[\mathrm{CuBr}_{1.5} \mathrm{~L}_{1.5}\right]_{2} \mathrm{Br}$ & $3300-3182$ & $3300-3182$ & 1608 & 1310 & 188 & 259 & - \\
\hline$\left[\mathrm{Cu}\left(\mathrm{OClO}_{3}\right) \mathrm{L}_{2}\right]_{2}\left(\mathrm{ClO}_{4}\right)_{2} \cdot 4 \mathrm{H}_{2} \mathrm{O}$ & $3600-3451(b)$ & 3186 & 1608 & 1303 & - & - & $\begin{array}{c}1184,1156,1100, \\
1045,621\end{array}$ \\
\hline
\end{tabular}


appeared at $160.30 \mathrm{ppm}$ and the assignments were made with the help of $\mathrm{C}-\mathrm{H}$ proton of azomethine group in the HMBC experiment. Further, hydroxyl proton showed cross peaks with quaternary carbons $2^{\prime \prime}, 1^{\prime \prime}$ and $1^{\prime}$.

Electronic spectral and magnetic moment studies: The electronic spectra of ligand and its copper(II) complexes were recorded in DMF. The spectra of free ligand displayed intense bands in the range 297-354 nm which was assigned to $\pi \rightarrow \pi^{*}$ and $\mathrm{n} \rightarrow \pi^{*}$ transitions. The spectra of copper complexes of 2[( $3^{\prime}$-N-salicylidinephenyl)benzimidazole] displayed absorption band in the range 707-778 $\mathrm{nm}$ which is attributed to $d-d$ transition arising out of square planar geometry [41]. The magnetic moment of copper(II) complexes are in the range 0.92-1.1 B.M. and is in consistence with one unpaired electron. The low magnetic moment is characteristic of antiferromagnetic coupling between two $\mathrm{Cu}(\mathrm{II})$ ions.

ESR spectral studies: ESR spectra of copper(II) complexes recorded at ambient and liquid nitrogen temperature (Fig. 2) showed no significant difference in the pattern. The ESR spectra of $\left[\mathrm{CuCl}_{2} \mathrm{~L}\right]_{2}$ and $\left[\mathrm{Cu}\left(\mathrm{OClO}_{3}\right) \mathrm{L}_{2}\right]_{2}\left(\mathrm{ClO}_{4}\right)_{2} \cdot 4 \mathrm{H}_{2} \mathrm{O}$ displayed two $\mathrm{g}_{\|}$and a $\mathrm{g}_{\perp}$ while $\left[\mathrm{CuBr}_{1.5} \mathrm{~L}_{1.5}\right]_{2} \mathrm{Br}$ showed only one peak due to $g_{\perp}$. The $g_{\|}$values were in the range 2.11-2.24 and $g_{\perp}$ in the range 2.04-2.09. The $\mathrm{g}_{\|}<2.3$ for the copper complexes suggested considerable covalent character in the metal-ligand bond. Further, $g_{\|}>g_{\perp}$ implied a $d_{x^{2}-y^{2}}$ ground state. The dimeric nature of the complexes have been supported by the observation of a weak ESR signal at $\mathrm{g} \approx 4.2$ corresponding to $\Delta \mathrm{Ms}= \pm 2$ spin forbidden transition in addition to a broad rhombic signal in the $\mathrm{g} \approx 2$ region [42].

Mass spectral studies: Mass spectrum of ligand exhibited $\mathrm{m} / \mathrm{z}$ peak at 314 corresponding to the molecular formula of the ligand. Mass spectra of $\left[\mathrm{CuCl}_{2} \mathrm{~L}\right]_{2},\left[\mathrm{CuBr}_{1.5} \mathrm{~L}_{1.5}\right]_{2} \mathrm{Br}$ and $\left[\mathrm{Cu}\left(\mathrm{OClO}_{3}\right) \mathrm{L}_{2}\right]_{2}\left(\mathrm{ClO}_{4}\right)_{2} \cdot 4 \mathrm{H}_{2} \mathrm{O}$, have supported the binuclear nature of the complexes [43]. These compounds exhibited molecular ion peaks at 896, 1395 and 1579 corresponding to $\mathrm{Cu}_{2} \mathrm{Cl}_{4} \mathrm{~L}_{2}$, $\mathrm{Cu}_{2} \mathrm{Br}_{3} \mathrm{~L}_{3}$ and $\mathrm{Cu}_{2}\left(\mathrm{OClO}_{3}\right)_{2} \mathrm{~L}_{4}$, respectively supporting the binuclear nature of these complexes.

Stereochemistry: A new Schiff base ligand and its copper complexes were synthesized. Conductivity measurements of chloro complexes suggested non-electrolytic behaviour while bromo complex exhibited $1: 1$ and for $\left[\mathrm{Cu}\left(\mathrm{OClO}_{3}\right) \mathrm{L}_{2}\right]_{2}\left(\mathrm{ClO}_{4}\right)_{2}$ $.4 \mathrm{H}_{2} \mathrm{O}$ exhibited 1:2 electrolytic behaviour. Thermogravimetric analysis data of perchlorato complex of copper suggested the presence of lattice water molecules in the complex. The results are in accordance with the composition of the complexes as deter- mined by elemental analyses. IR spectral studies indicated the coordination of the ligand to the central metal atom through tertiary nitrogen of benzimidazole as well as nitrogen atom of azomethine moiety behaving as both monodentate and bridging bidentate.

Electronic spectra of the copper complexes indicated square planar geometry around metal ion. Chloro complex of copper was analyzed for the formula $\left[\mathrm{CuCl}_{2} \mathrm{~L}\right]_{2}$. ESR and mass spectral analysis supported dimeric structure. Far-IR spectrum indicated the presence of terminal chlorides. Hence a binuclear structure with ligand acting as bridging bidentate has been suggested for the $\left[\mathrm{CuCl}_{2} \mathrm{~L}\right]_{2}$ complex (Fig. 3a).

The bromo complex of copper analyzed for the formula $\mathrm{Cu}_{2} \mathrm{Br}_{4} \mathrm{~L}_{3}$. ESR and mass spectral studies supported dimeric nature of the complex. Far-IR spectrum indicated the presence of both bridging and terminal bromides and the complex showed 1:1 electrolytic behaviour. Based on these studies, binuclear structure with one ligand acting as bridging bidentate and other two as monodentate has been suggested (Fig. 3b).

Perchlorato complex of copper analyzed for the formula $\mathrm{Cu}_{2} \mathrm{~L}_{4}\left(\mathrm{ClO}_{4}\right)_{4}$. ESR and mass spectral analysis revealed its dimeric nature. The complex showed 1:2 electrolytic behaviour. IR spectrum indicated the presence of both ionic and monodentately coordinated perchlorate groups. Based on these studies, the complex has been assigned binuclear structure wherein the two ligands acting as bridging bidentate and two as monodentately coordinated to the metal ion (Fig. 3c).

Antibacterial activity: The ligand and the synthesized complexes were screened against five different bacterial (Table3) strains. The compounds, control (DMSO) and standard drug ampicillin were screened against two Gram-positive bacteria, Staphylococcus aureus and Bacillus cereus, three Gram- negative bacteria Escherichia coli, Salmonella typhi and Pseudomonas aerugenosa. Varying degree of inhibitory effect was observed against these bacteria. The Schiff base, 2-[(3'-N-salicylidinephenyl)benzimidazole] was not sensitive to bacterial strains except for E. coli. In general, antibacterial activity increased upon complexation [44]. All the complexes did not show inhibition effect on Bacillus cereus. All the copper complexes exhibited excellent antibacterial activity against $P$. aerugenos $a$ and found to be more effective than the standard drug. Perchlorato complex of copper was found not sensitive towards Gram-positive bacteria, Staphylococcus aureus and Bacillus cereus. Antibacterial activity was found to increase with increase in the concentration of the test solution. The increase in toxicity may be due to reduction

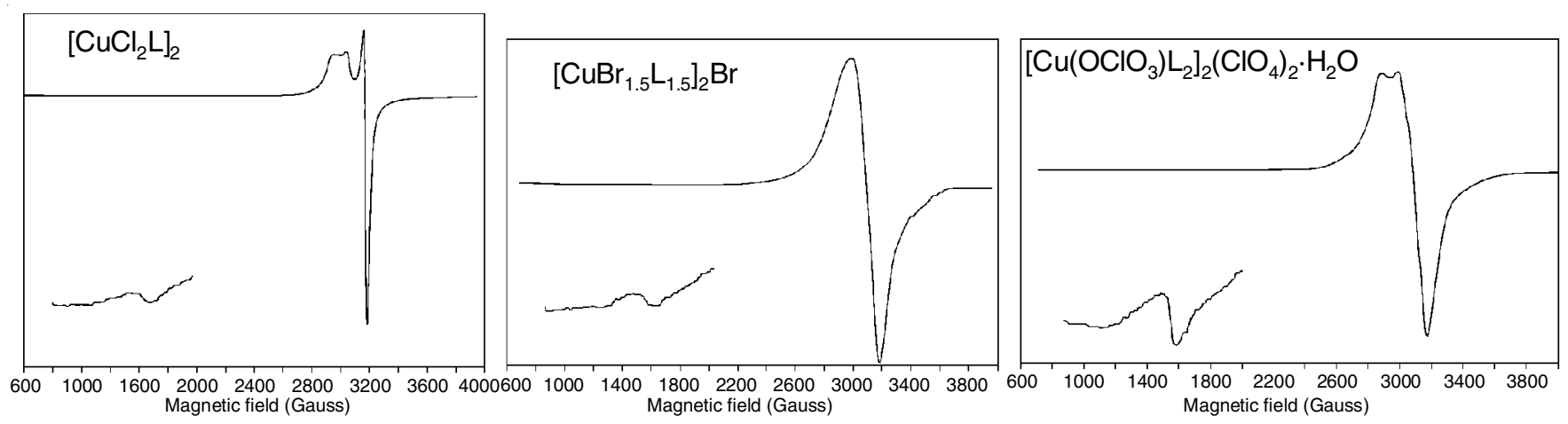

Fig. 2. ESR spectra of $\mathrm{Cu}$ (II) complexes 


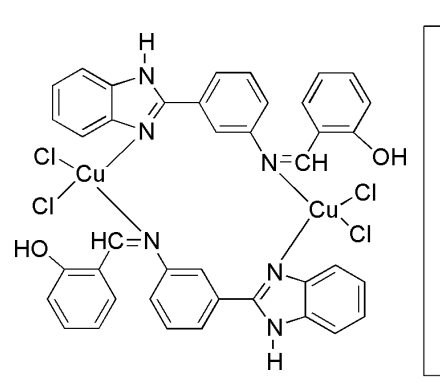

(a)

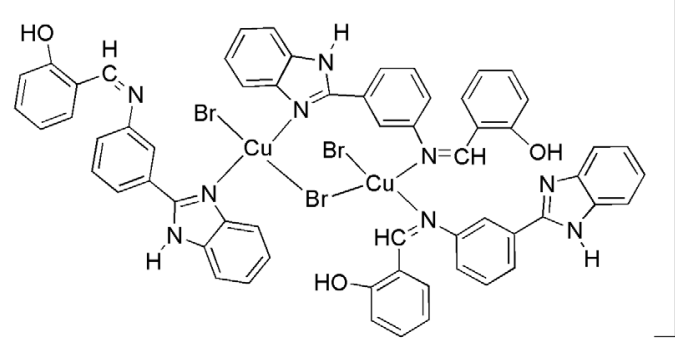

(b)

Fig. 3. Sterochemistry of the complexes

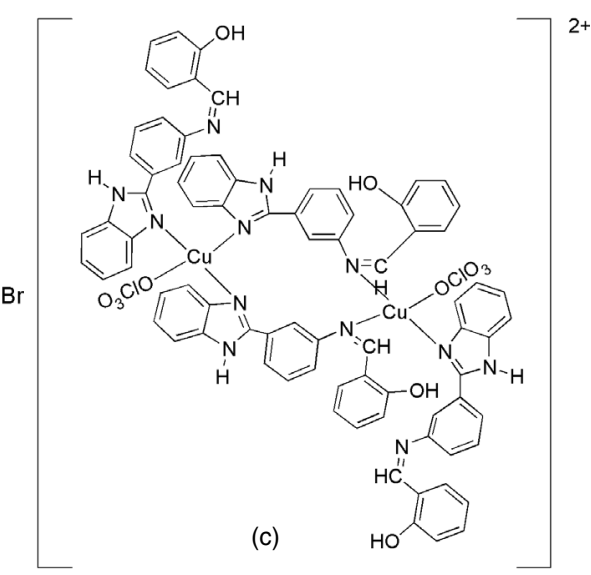

TABLE-3

ANTIBACTERIAL ACTIVITY

\begin{tabular}{|c|c|c|c|c|c|c|c|c|c|c|}
\hline \multirow{2}{*}{ Complex } & \multicolumn{4}{|c|}{ Concentration (ppm) } & \multirow{2}{*}{$\begin{array}{c}\% \text { Activity index } \\
(100 \text { ppm })\end{array}$} & \multicolumn{4}{|c|}{ Concentration (ppm) } & \multirow{2}{*}{$\begin{array}{l}\text { \% Activity index } \\
(100 \mathrm{ppm})\end{array}$} \\
\hline & 25 & 50 & 75 & 100 & & 25 & 50 & 75 & 100 & \\
\hline & \multicolumn{5}{|c|}{ Staphylococcus aureus } & \multicolumn{5}{|c|}{ Escherichia coli } \\
\hline$\left[\mathrm{CuCl}_{2} \mathrm{~L}\right]_{2}$ & 12 & 12 & 13 & 13 & 62 & - & - & - & - & - \\
\hline$\left[\mathrm{CuBr}_{1.5} \mathrm{~L}_{1.5}\right]_{2} \mathrm{Br}$ & 13 & 13 & 16 & 17 & 81 & 12 & 13 & 14 & 14 & 70 \\
\hline$\left[\mathrm{Cu}\left(\mathrm{OClO}_{3}\right) \mathrm{L}_{2}\right]_{2}\left(\mathrm{ClO}_{4}\right)_{2} \cdot 4 \mathrm{H}_{2} \mathrm{O}$ & - & - & - & - & - & - & - & - & - & - \\
\hline Ligand & - & - & - & - & - & 15 & 15 & 16 & 17 & 85 \\
\hline \multirow{2}{*}{ Ampicillin } & 14 & 15 & 18 & 21 & 100 & 14 & 16 & 17 & 20 & 100 \\
\hline & \multicolumn{5}{|c|}{ Salmonella typhi } & \multicolumn{5}{|c|}{ Pseudomonas aeruginosa } \\
\hline$\left[\mathrm{CuCl}_{2} \mathrm{~L}\right]_{2}$ & - & - & - & 15 & 75 & 29 & 29 & 31 & 33 & 132 \\
\hline$\left[\mathrm{CuBr}_{1.5} \mathrm{~L}_{1.5}\right]_{2} \mathrm{Br}$ & - & - & 13 & 13 & 65 & 15 & 15 & 24 & 25 & 100 \\
\hline$\left[\mathrm{Cu}\left(\mathrm{OClO}_{3}\right) \mathrm{L}_{2}\right]_{2}\left(\mathrm{ClO}_{4}\right)_{2} \cdot 4 \mathrm{H}_{2} \mathrm{O}$ & - & - & 12 & 13 & 65 & 25 & 27 & 27 & 30 & 120 \\
\hline Ligand & - & - & - & - & - & - & - & - & - & - \\
\hline Ampicillin & 15 & 16 & 17 & 20 & 100 & 16 & 18 & 20 & 25 & 100 \\
\hline
\end{tabular}

of polarity of the metal ion due to coordination of ligands and $\pi$-electron delocalization. Such coordination enhances lipohilic character of the central metal atoms that favours permeation of the complexes through the lipid layers of cell membrane and increases the antimicrobial activity. According to Overtone's concept of cell permeability [45], only lipid soluble materials pass through the lipid membrane that surrounds the cell. Hence, the antimicrobial activity depends on liposolubility.

Antifungal activity: The complexes, DMSO control and the standard drug were screened against two fungal species, Aspergillus flavus and Trichoderma. Although the complexes exhibited activity (Table-4) against Trichoderma, they did not reach the effectiveness of the standard drug, fucanozole. Bromo complex of copper showed activity against Aspergillus flavus.

\begin{tabular}{lcc|cc}
\multicolumn{4}{c}{ TABLE-4 } \\
ANTIFUNGAL ACTIVITY (ZONE INHIBITION IN mm) \\
\hline \multirow{2}{*}{ Complexes } & \multicolumn{2}{c|}{$\begin{array}{c}\text { Aspergillus } \\
\text { flavus }\end{array}$} & \multicolumn{2}{c}{ Trichoderma } \\
\cline { 2 - 6 } & $\begin{array}{c}100 \\
\text { ppm }\end{array}$ & $\begin{array}{c}\text { Activity } \\
\text { index }\end{array}$ & $\begin{array}{c}100 \\
\text { ppm }\end{array}$ & $\begin{array}{c}\% \\
\text { Activity } \\
\text { index }\end{array}$ \\
\hline$\left[\mathrm{CuCl}_{2} \mathrm{~L}_{2}\right.$ & - & - & 6 & 55 \\
{$\left[\mathrm{CuBr}{ }_{1.5} \mathrm{~L}_{1.5}\right]_{2} \mathrm{Br}$} & 4 & 50 & 4 & 36 \\
{$\left[\mathrm{Cu}\left(\mathrm{OClO}_{3}\right) \mathrm{L}_{2}\right]_{2}\left(\mathrm{ClO}_{4}\right)_{2} \cdot 4 \mathrm{H}_{2} \mathrm{O}$} & - & - & 5 & 45 \\
$\mathrm{Ligand}$ & 2 & 25 & 3 & 27 \\
Fucanozole & 8 & 100 & 11 & 100 \\
\hline
\end{tabular}

\section{Conclusion}

Binuclear complexes of $\mathrm{Cu}$ (II) of a Schiff base ligand, 2[(3'-N-salicylidinephenyl)benzimidazole] were prepared and characterized. Antibacterial and antifungal studies of these complexes were investigated. All the sythesized copper complexes exhibited excellent antibacterial activity against $P$. aerugenosa and found to be more effective than the standard drug.

\section{ACKNOWLEDGEMENTS}

The authors thank Spectroscopy Analytical Test Facility, IISc, Bangalore, India for ESI-MS, Pondicherry University, Puducherry, India, for far-IR spectra and magnetic susceptibility measurements, SAIF, IIT, Bombay for ESR spectra, STIC, CUSAT, Cochin, India for elemental and thermal analyses.

\section{CONFLICT OF INTEREST}

The authors declare that there is no conflict of interests regarding the publication of this article.

\section{REFERENCES}

1. T. Sakai, T. Hamada, N. Awata and J. Watanabe, J. Pharmacobiodyn., 12, 530 (1989); https://doi.org/10.1248/bpb1978.12.530.

2. A.A. Spasov, I.N. Yozhitsa, L.I. Bugaeva and V.A. Anisimova, Pharm. Chem. J., 33, 232 (1999); https://doi.org/10.1007/BF02510042. 
3. R.A. Bucknall and S.B. Carter, Nature, 213, 1099 (1967); https://doi.org/10.1038/2131099a0.

4. F. Gumus, O. Algul, G. Eren, H. Eroglu, N. Diril, S. Gür and A. Özkul, Eur. J. Med. Chem., 38, 473 (2003); https://doi.org/10.1016/S0223-5234(03)00058-8.

5. M. Gökçe, S. Utku, S. Gür, A. Özkul and F. Gümüs, Eur. J. Med. Chem., 40, 135 (2005); https://doi.org/10.1016/j.ejmech.2004.09.017.

6. N. Bharti, M.T. Shailendra, M.T. Gonzalez Garza, D.E. Cruz-Vega, J. Castro-Garza, K. Saleem, F. Naqvi, M.R. Maurya and A. Azam, Bioorg. Med. Chem. Lett., 12, 869 (2002);

https://doi.org/10.1016/S0960-894X(02)00034-3.

7. Y. Elerman, M. Kabak and A. Elmali, Z. Natruforsch., 57, 651 (2002); https://doi.org/10.1515/znb-2002-0610.

8. N. Chantarasiri, V. Ruangpornvisuti, N. Muangsin, T. Mananunsap, H. Detsen, C. Batiya and N. Chaichit, Spectrochim. Acta A Mol. Biomol. Spectrosc., 61, 157 (2005); https://doi.org/10.1016/j.saa.2004.03.015.

9. N. Chantarasiri, V. Ruangpornvisuti, N. Muangsin, T. Mananunsap, H. Detsen, C. Batiya and N. Chaichit, J. Mol. Struct., 701, 93 (2004); https://doi.org/10.1016/j.molstruc.2004.05.015.

10. A.A. Soliman and G.G. Mohamed, Thermochim. Acta, 421, 151 (2004); https://doi.org/10.1016/j.tca.2004.03.010.

11. J. Kaizer, Z. Zsigmond, I. Ganszky, G. Speier, M. Giorgi and M. Réglier, Inorg. Chem., 46, 4660 (2007); https://doi.org/10.1021/ic062309a.

12. E. Tas, I. Ucar, V.T. Kasumov, A. Kilic and A. Bulut, Spectrochim. Acta A Mol. Biomol. Spectrosc., 68, 463 (2007); https://doi.org/10.1016/j.saa.2006.11.052.

13. E. Tas, V. Kasumov, O. Sahin and M. Özdemir, Transition Met. Chem., 27, 442 (2002) https://doi.org/10.1023/A:1015011517647.

14. J. Cui and M. Zhang, J. Chem. Res., 34, 41 (2010); https://doi.org/10.3184/030823410X12628736648105.

15. M. Ulusoy, O. Sahin, O. Büyükgüngör and B. Çetinkaya, J. Organomet. Chem., 693, 1895 (2008); https://doi.org/10.1016/j.jorganchem.2008.02.017.

16. N. Bharti, M.R. Maurya, F. Naqvi and A. Azam, Bioorg. Med. Chem. Lett., 10, 2243 (2000); https://doi.org/10.1016/S0960-894X(00)00446-7.

17. G. Wilkinson, Comprehensive Coordination Chemistry, Pergamon Press: Oxford, vol. 5, p. 775 (1987).

18. K.D. Karlin and J. Zubieta, Copper Coordination Chemistry, Biochemical and Inorganic perspective, Adenine Press, Guilderland: New York (1983-1986).

19. J. Gaazo, I.B. Bersuker, J. Garaj, M. Kabesova, H. Langfelderova, J. Kojout, M. Melnik, M. Serator and F. Valach, Coord. Chem. Rev., 19, 253 (1976); https://doi.org/10.1016/S0010-8545(00)80317-3.

20. M. Palaniandavar, R.J. Butcher and A.W. Addison, Inorg. Chem., 35, 467 (1996); https://doi.org/10.1021/ic941396g.

21. A. Benzekri, P. Dubourdeaux, J.M. Latour, P. Rey and J. Laugier, J. Chem. Soc., Dalton Trans., 3359 (1991); https://doi.org/10.1039/dt9910003359.

22. J.D. Crane and D.E. Fenton, Polyhedron, 10, 1809 (1991); https://doi.org/10.1016/S0277-5387(00)83804-8.

23. H.P. Berends and D.W. Stephan, Inorg. Chim. Acta, 99, L53 (1985); https://doi.org/10.1016/S0020-1693(00)87956-6.
24. J.D. Crane, R. Hughes and E. Sinn, Inorg. Chim. Acta, 237, 181 (1995); https://doi.org/10.1016/0020-1693(95)04653-Q.

25. V. Mckee, J.V. Dagdigian, R. Bau and C.A. Reed, J. Am. Chem. Soc., 103, 7000 (1981); https://doi.org/10.1021/ja00413a054.

26. H.J. Hoorn, P. de Joode, W.L. Driessen and J. Reedijk, React. Funct. Polym., 27, 223 (1995); https://doi.org/10.1016/1381-5148(95)96870-G.

27. P.M. van Berkel, D.J. Dijkstra, W.L. Driessen, J. Reedijk and D.C. Sherrington, React. Funct. Polym., 28, 39 (1995); https://doi.org/10.1016/1381-5148(95)00078-2.

28. D.D. Perrin, Armarego and D.R. Perrin, Purification of Laboratory Chemicals, Pergamon Press Pvt Ltd: Oxford, edn 1 (1966).

29. B. Roopashree, V. Gayathri and H. Mukund, J. Coord. Chem., 65, 1354 (2012); https://doi.org/10.1080/00958972.2012.673123.

30. G.R. Suman, G. Bubbly, S.B. Gudennavar, S. Muthu, B. Roopashree, V. Gayatri and N.M. Nanje Gowda, J. Mol. Struct., 1139, 247 (2017); https://doi.org/10.1016/j.molstruc.2017.03.043.

31. W.I. Geary, Coord. Chem. Rev., 7, 81 (1971); https://doi.org/10.1016/S0010-8545(00)80009-0.

32. G. Mohamed, S.A. Salam, S. Oumar, U. Russo and V. Maurizio, Polyhedron, 14, 655 (1995); https://doi.org/10.1016/0277-5387(94)00295-P.

33. G. Bombieri, E. Benetollo, A. Polo, L. De Cola, D.L. Smailes and L.M. Vallarino, Inorg. Chem., 25, 1127 (1986); https://doi.org/10.1021/ic00228a014.

34. L. De Cola, D.L. Smailes and L.M. Vallarino, Inorg. Chem., 25, 1729 (1986); https://doi.org/10.1021/ic00230a042.

35. M.P. Ngwenya, D. Chen, A.E. Martell and J. Reibenspies, Inorg. Chem., 30, 2732 (1991); https://doi.org/10.1021/ic00013a006.

36. W. Coleman and L.T. Taylor, Inorg. Chem., 10, 2195 (1971); https://doi.org/10.1021/ic50104a021.

37. K. Nakamoto, Infrared and Raman Spectra of Inorganic and Coordination Compounds, Wiley Interscience, New York, edn 4 (1986).

38. N.M.N. Gowda, S.B. Naikar and G.K.N. Reddy, Adv. Inorg. Chem. Radiochem., 28, 255 (1984); https://doi.org/10.1016/S0898-8838(08)60210-X.

39. A. Bax and M.F. Summers, J. Am. Chem. Soc., 108, 2093 (1986); https://doi.org/10.1021/ja00268a061.

40. W. Willker, D. Leibfritz, R. Kerssebaum and W. Bermel, Magn. Reson. Chem., 31, 287 (1993); https://doi.org/10.1002/mrc.1260310315.

41. A.B.P. Lever, Inorganic Electronic Spectroscopy, Elsevier: New York (1968).

42. A. Piguet, B. Bocquet, E. Muller and A.F. Williams, Helv. Chim. Acta, 72, 323 (1989); https://doi.org/10.1002/hlca.19890720218.

43. R.M. Silverstein, G.C. Bassler and T.C. Morril, Spectroscopic Identification of Organic Compounds, Wiley: Singapore, edn 4 (1981).

44. R. Nagar, Inorg. Biochem., 40, 349 (1990); https://doi.org/10.1016/0162-0134(90)80069-A.

45. Y. Anjaneyulu and R.P. Rao, Synth. React. Inorg. Met.-Org. Chem., 26, 257 (1986); https://doi.org/10.1080/00945718608057530. 